\title{
A modelling study of the variation of thermal conductivity of the English Chalk
}

Jon Busby

\author{
British Geological Survey, Keyworth, Nottingham, NG12 5GG, UK.
}

Email jpbu@bgs.ac.uk

\section{Abstract}

Thermal conductivity is required when designing ground heating and cooling schemes, electrical cable conduits and tunnel ventilation. In England these infrastructures are often emplaced within the Chalk. To improve knowledge on chalk thermal conductivity, over the few scattered measured values, estimates have been made from multi-component mixture models based on the mineral composition, porosity and the structure of the Chalk. The range in mid values for the thermal conductivities is $1.78-2.57 \mathrm{~W} \mathrm{~m}^{-1} \mathrm{~K}^{-1}$ where the lowest values are for the Upper Chalk. Variations in porosity are the main factor for the variation in thermal conductivity. The effect of fracturing is to reduce the bulk thermal conductivity, but the reduction is small for fractures that are saturated. For an averagely fractured chalk with $60 \%$ fracture saturation, the reduction in thermal conductivity is around $22 \%$ for a thermal conductivity of $2.15 \mathrm{~W} \mathrm{~m}^{-1} \mathrm{~K}^{-1}$. In the near surface zone, where fracture apertures will be at their greatest and unsaturated conditions may prevail for part of the year, the seasonal variation in thermal conductivity may be significant for infrastructure design.

\section{Introduction}

Thermal conductivity is the capacity of a material to conduct or transmit heat (Somerton, 1992). It is an essential parameter to the understanding of the movement of heat by conduction in the subsurface. The design of infrastructure, such as ground heating and cooling schemes, electrical cable conduits and tunnels requiring ventilation, need accurate estimates of thermal conductivity. It is measured by steady state or transitory methods that measure a temperature change created by an applied heat flow through a sample of rock or through the greater rock 
mass. In some rocks, thermal conductivity is anisotropic and for crystalline rocks it decreases with increasing temperature.

Chalk is a very fine-grained soft, white limestone containing a very high percentage of calcium carbonate $\left(\mathrm{CaCO}_{3}\right)$ with some marl bands and flint (Hancock, 1975). The Chalk Group in England was deposited in two lithological and faunal provinces ascribed to a southern province (Southern England) and a northern province (north Lincolnshire and east Yorkshire) with an intermediate region in East Anglia. The intermediate region is often referred to as being part of the southern province. This Technical Note presents modelled values of thermal conductivity for the English Chalk as a method of capturing the regional variations in a more systematic manner than is possible from the few, scattered, measured values.

\section{Laboratory derived thermal conductivity}

Most measured thermal conductivity values on the Chalk have been undertaken in the laboratory using a needle probe or the divided bar apparatus on drill chippings. Such measurements are only representative of chalk at a specific location and only give a matrix value as opposed to a bulk value that would include the influence of marl bands, flint and fracturing. The majority of these laboratory measurements were taken as part of the 'Investigation of the geothermal potential of the UK' programme and are presented as mean values in Table 1. It should be noted that these measurements were made before the adoption of the new Chalk stratigraphy (Hopson, 2005; Mortimore, 2001, 2011) and hence are referenced to the old stratigraphy of Upper, Middle and Lower Chalk and this is maintained throughout this Technical Note, however the correlations between the old and new Chalk stratigraphy are shown in Table 2. The data in Table 1 suggest that in the southern province the Upper Chalk has the lowest thermal conductivity with a range of values for the Middle and Lower Chalk. Combining all the data gives a Chalk (undifferentiated) thermal conductivity of $1.86 \mathrm{~W} \mathrm{~m}^{-1} \mathrm{~K}^{-1}$ for the southern province. The Chalk of the northern province is attributed with a much higher thermal conductivity $\left(3.27-3.83 \mathrm{~W} \mathrm{~m}^{-1} \mathrm{~K}^{-1}\right)$, possibly indicating a clear distinction between the southern and northern chalks. However, the thermal conductivity of $\mathrm{CaCO}_{3}$ is 
around $3.59 \mathrm{~W} \mathrm{~m}^{-1} \mathrm{~K}^{-1}$ (Clauser and Huenges, 1995) and hence this would only be possible if the chalk had no porosity or a significant quantity of an impurity of high thermal conductivity. As these data are only from the Cleethorpes borehole there is also the possibility of a systematic error in the measurements and this will be explored in the sections below.

\section{Lithology and structure of the Chalk}

The new Chalk stratigraphy also classifies the Chalk into the White Chalk subgroup (broadly Middle and Upper Chalk) and the Grey Chalk subgroup (Lower Chalk) (see Table 2). The White Chalk is homogeneous and contains greater than $95 \% \mathrm{CaCO}_{3}$ (Mortimore 2012). In the southern province the non-carbonate fraction is dominated by quartz, montmorillonite, illite, muscovite and some glauconite (Hancock, 1975; Morgan-Jones, 1977). In the northern province the White Chalk is described as $98 \% \mathrm{CaCO}_{3}$ with the non-carbonate fraction dominated by montmorillonite and illite with small amounts of detrital quartz and feldspar (Gale and Rutter, 2006). The Grey Chalk is a marly chalk with a high proportion of terrigenous sediment that decreases upwards (Allen et al., 1997). Destombes and Shephard-Thorn (1971) produced a calcimetry profile of the Grey Chalk of the southern province. It showed the content of $\mathrm{CaCO}_{3}$ increasing from around $45 \%$ to $90 \%$ from the base to the top of the Grey Chalk. The non-carbonate fraction comprises clay minerals with some silt grade quartz and authigenic pyrite in the southern province (Jones and Robins, 1999) and small amounts of detrital quartz and feldspar in the northern province (Gale and Rutter, 2006).

The porosity of the chalk is known to be generally high due to sedimentation and resedimentation processes during diagenesis (Bloomfield et al., 1995), although its matrix permeability is low due to unusually small pore diameters and pore throat sizes (Allen et al., 1997). Regional variations in chalk porosity based on over 2000 porosity tests are reported by Bloomfield et al. (1995) who split the data into four geographical areas comprising southern England, Thames and Chilterns, East Anglia and northern England (see Figure 1). Maximum mean porosity of $38.8 \%$ was found for the southern province Upper Chalk and a minimum 
mean of $18.9 \%$ for the northern province Middle Chalk. The permeability of the chalk arises from fracture flow which is generally only developed towards the top of the aquifer due to fracture closure and reduced groundwater movement, and hence reduced dissolution, at depth (Allen et al., 1997). The two dominant fracture sets are parallel to bedding or at a high angle to bedding. In the southern province Bevan and Hancock (1986) described vertical joint spacings in the range 0.1-1.0 m, Younger and Elliot (1995) measured joint spacings parallel and normal to bedding with ranges of $0.08-1.0 \mathrm{~m}$ and $0.11-2.0 \mathrm{~m}$ respectively and Mortimore (2012) reported vertical joint spacings of $0.16-1.16 \mathrm{~m}$. In the northern province Patsoules and Cripps (1990) reported vertical joint spacings in the range $0.15-0.33 \mathrm{~m}$. There are few direct observations of fracture apertures, but in the southern province Mortimore (2012) reports apertures of 1-4 mm, and Younger and Elliot (1995) inferred apertures in the range 0.45-0.9 $\mathrm{mm}$ from the geochemical modelling of radon activity. From measurements along a single bedding plane fracture in the southern province Bloomfield (1996) reported apertures from 0.5-23.5 $\mathrm{mm}$ although the larger apertures were attributed to solution processes. In the northern province, Patsoules and Cripps (1990) measured apertures in the range 0.1-0.6 mm.

Marl bands occur throughout the Chalk. They can be up to several centimetres thick and some are laterally continuous for several hundreds of kilometres (Allen et al., 1997). The marl seams have been used extensively as marker horizons for correlation purposes (Mortimore 1986). They are generally considered to be derived from contemporary airborne volcanic ash falls and are rich in smectite (Allen et al., 1997). However, Wray and Jeans (2014) reported that many of the marl seams only contain $3-10 \%$ of non-carbonate minerals and may be of detrital origin and that the volcanically derived marl seams are more appropriately described as bentonites. Published data on the percentage of the Chalk that is comprised of the marl bands is lacking. However, Gale and Rutter (2006) report that the upper unit of the Upper Chalk of the northern province (Flamborough Formation) has numerous marl seams typically 1 to $3 \mathrm{~cm}$ in thickness that occur with an average frequency of almost one per metre, but that this is far more abundant than in the underlying Chalks. This implies a maximum marl band content of 
around 3\%. From data presented in Mortimore (2011) the marl band content in the Upper

108 Chalk of the southern province may be around $1.5 \%$.

Flint is associated with chalk and is found in layers parallel to bedding or as scattered discreet nodules (Allen et al., 1997). Flint is a variety of chert, sometimes referred to as cryptocrystalline quartz, comprising very fine quartz crystals arranged in a random mosaic leaving a number of minute cavities filled with water (Hancock, 1975). The layers generally occur as sheets, which are usually thin $(1-5 \mathrm{~cm})$ or as layers of nodules $(5-15 \mathrm{~cm}$ thick) (Mortimore, 2012). In the sheets, flint has replaced subhorizontal and/or subvertical shear planes, whilst the nodules have been shown to be the infills of burrow systems of animals that lived on the sea bed (Bromley, 1967). Where the flint nodules are so abundant that they coalesce into a more or less continuous bed, they are referred to as a tabular flint. In the southern province the Lower and Middle Chalk are generally flintless, whilst there are numerous flint bands within the Upper Chalk (Allen et al., 1997). It is similar in the northern province (generally flintless Lower and Middle Chalk), but the lower formation (Burnham Formation) of the Upper Chalk has frequent flint bands, compared to the upper formation (Flamborough Formation) which is flintless. In the coastal area of Holderness there is an additional unit above the Flamborough Formation, called the Rowe Chalk Formation that contains flint bearing beds (Gale and Rutter, 2006). Mortimore and Wood (1986) report a flint maximum that is seen across the southern and northern provinces and occurs near the top of the Turonian stage (near the base of the Upper Chalk; see Table 2). As with the marl bands, the flint layers have been extensively mapped and used as marker horizons for lithostratigraphic correlations. However, there is very little published data on the quantity of flint within the chalk. Dornbusch (2005) and Dornbusch et al. (2006) calculated flint percentages within the Upper Chalk of the southern province from digital photographs of the cliffs between East Sussex and Kent. They found the percentage decreased from around 4.5\% to $1.5 \%$ from the base (Lewes Chalk Formation) to the top (Culver Chalk Formation) of the Upper Chalk, indicating an average of around 3\%. Mortimore (2012) reported an assessment 
of flint from the top of the Upper Chalk of the southern province (Culver Chalk Formation) as part of the Shoreham Harbour tunnel site investigations. The spacing of flint bands was found to range from $1.23-2.33 \mathrm{~m}$ with flints $15-20 \mathrm{~cm}$ across. Analyses showed that flint percentages were likely to be $5 \%$ or greater.

\section{Modelling of Chalk thermal conductivity}

The modelling is based on multi-component mixture models, as summarised by Clauser (2006). Due to their well-defined compositions, the thermal conductivities of minerals show a much smaller variance than rocks and can be combined with the thermal conductivities of the saturating fluids to estimate the thermal conductivity of the rock. For randomly composed mixtures, such as the matrix of the rock, the geometric mean model is preferred. In this case the geometric mean thermal conductivity of an n-component system is the product of the thermal conductivity of each component raised to the power of its fractional component, i.e.,

$$
\lambda_{m}=\prod_{i=1}^{n} \lambda_{i} \varphi_{i}
$$

where $\lambda_{m}$ is the mean matrix thermal conductivity, $\lambda_{\mathrm{i}}$ is the thermal conductivity of the ith component and $\varphi_{i}$ is the fractional proportion of the ith component.

Chalk comprises a bedded sequence in which the matrix is layered with marl and flint bands. When the heat flow is perpendicular to the layers (i.e. geothermal heat flux, seasonal temperature changes) the thermal conductivity is calculated with a harmonic mean model, i.e.,

$$
\frac{1}{\lambda_{l}}=\sum_{i=1}^{n} \frac{\varphi_{i}}{\lambda_{i}}
$$

where $\lambda_{\mathrm{I}}$ is the mean layered thermal conductivity, $\lambda_{\mathrm{i}}$ is the thermal conductivity of the ith layer and $\varphi_{i}$ is the fractional thickness of the ith layer. In the event of any vertical contacts within the chalk, i.e. vertically orientated fractures where the heat flow is parallel to the fractures, the 
layered thermal conductivity is modified with an arithmetic mean model to derive a bulk thermal conductivity, i.e.,

$$
\lambda_{b}=\sum_{i=1}^{n} \varphi_{i} \lambda_{i}
$$

where $\lambda_{b}$ is the mean bulk thermal conductivity, $\lambda_{i}$ is the thermal conductivity of the ith vertical component and $\varphi_{i}$ is the fractional width of the ith component. Mixing models are not based on physical models and so do not take into account factors such as the geometrical relationships between the different mineral components and so all have their limitations. Most of the multi-component mixture models work to within 10\%-15\% accuracy (Clauser, 2006).

Hence, the modelling strategy has been to derive a bulk thermal conductivity by a sequential application of the mixture models. Figure 2 shows a schematic diagram of the chalk used in the modelling. The matrix thermal conductivity has been derived by combining the mineralogy and porosity (that is assumed to be water filled) with a geometric mean model. The marl and flint bands were then taken into account to generate a layered thermal conductivity with the harmonic mean model. Finally, the influence of fracturing has been considered with a minimum and a maximum jointed/fractured model in which the proportion of space occupied by the fractures has been estimated. For the minimum fracture case it has been assumed that the bedding plane fracture spacing is $1 \mathrm{~m}$ and the fractures have an aperture of $0.1 \mathrm{~mm}$, creating a minimum proportional space of 0.0001 . Vertically orientated fractures are assumed to have a spacing of $1 \mathrm{~m}$ and an aperture of $0.5 \mathrm{~mm}$, creating a minimum proportional space of 0.0005 . For the maximum fracture case the bedding plane fracture spacing is $0.05 \mathrm{~m}$ with an aperture of $0.7 \mathrm{~mm}$, creating a maximum proportional space of 0.014 . The vertical fractures are assumed to have a spacing of $0.1 \mathrm{~m}$ with an aperture of $5.0 \mathrm{~mm}$, creating a maximum proportional space of 0.05 . To calculate the bulk thermal conductivities a series of models have been run in which the proportion of facture space increases from the minimum to the maximum case, with the bedding plane fractures incorporated with the harmonic mean model 
181

182

\section{Results}

and the vertical fractures with the arithmetic mean model. In addition separate models were run for fracture saturations of $0 \%, 20 \%, 40 \%, 60 \%, 80 \%$ and $100 \%$.

Table 3 lists the input data used to derive the matrix and layered thermal conductivities for the Upper, Middle and Lower Chalk in the southern and northern provinces. The thermal conductivities attributed to the model components are listed in Table 4. Thermal conductivity ranges have been derived and are quoted as minimum, mid and maximum values. For the input data, porosity ranges are from Bloomfield et al. (1995) and comprise the $10^{\text {th }}, 50^{\text {th }}$ and $90^{\text {th }}$ percentiles of the measured populations except for the northern England Lower Chalk which is from Barker (1994) and comprises the mean with minimum and maximum porosities estimated as two standard deviations from the mean. Flint ranges in the Upper Chalk are $1.5 \%, 3 \%$ and $15 \%$ with the maximum value estimated from Mortimore and Wood (1986). The marl seams have not been considered over a range as the thermal conductivity of the marl seam (2.05 W m-1 $\mathrm{K}^{-1}$; see Table 3 for its composition) is similar to chalk and over the low percentages of marl from the seams has minimal effect on the chalk bulk thermal conductivity. The layered thermal conductivities are tabulated in Table 5. These can be considered as the bulk thermal conductivities if the effect of fracturing is not taken into account.

In order to illustrate the effect of fracturing, a fracture model was run for the mid-range thermal conductivity of $2.15 \mathrm{~W} \mathrm{~m}^{-1} \mathrm{~K}^{-1}$ from Table 5 . The results are presented in graphical form in Figure 3 as thermal conductivity against fracture space by proportional volume for a range of fracture saturations. It has been assumed that there are no fracture fillings, such as fragmented flint, clay coated gravel or sand sized aggregates of chalk clasts as reported by Bloomfield (1996).

\section{Discussion}


The range in mid values for the layered thermal conductivities is $1.78-2.57 \mathrm{~W} \mathrm{~m}^{-1} \mathrm{~K}^{-1}$ where the lowest values are for the Upper Chalk due to the higher porosities observed in both the southern and northern provinces. The highest thermal conductivities are for the northern England Middle Chalk due to the lowest porosities. The effect of the marl seams on the thermal conductivity is negligible and that of flint, only in regions of flint maximum. Increasing the flint volume from $3-15 \%$ increases the thermal conductivity by around $5-6 \%$. In the northern province Upper Chalk, the Flamborough Formation is flint free, resulting in a modelled range in thermal conductivity of $1.71-1.81-2.31 \mathrm{~W} \mathrm{~m}^{-1} \mathrm{~K}^{-1}$, which can be compared to the values in Table 5 that relate to the flint bearing Burnham Formation. Figure 3 illustrates the reduction in thermal conductivity due to fracturing. For fractures in the saturated zone the maximum reduction is only $7 \%$. In the unsaturated zone the reductions are more significant; at a fracture volume of 0.03 , thermal conductivity is reduced by $13 \%$ at $80 \%$ saturation and by $33 \%$ at $20 \%$ saturation. Since fracture apertures are likely to be greater in the near surface unsaturated zone than at depth, the level of saturation is important for thermal conductivity. It is also possible that there will a seasonal variation of thermal conductivity that may affect the performance of infrastructure within the unsaturated zone. With a lowering of the water table in the summer, a closed loop GSHP borehole will operate less effectively than in the winter and a dry winter could lead to less efficient operation when heating is required the most. In a similar manner, tunnel ventilation will be most affected in the summer when cooling is most needed. The mean seasonal water level variation across the unconfined (outcrop) Chalk is about $5 \mathrm{~m}$ and variations are generally less than $32 \mathrm{~m}$. The maximum seasonal water level variation is about $40 \mathrm{~m}$ and there is a higher concentration of $>30 \mathrm{~m}$ variation in the Chalk of southern England. The effect on thermal conductivity can be illustrated using the fracture results above. For a $100 \mathrm{~m}$ deep vertical borehole in Chalk of bulk thermal conductivity 2.15 $\mathrm{W} \mathrm{m} \mathrm{m}^{-1} \mathrm{~K}^{-1}$, for a drop in water level of $5 \mathrm{~m}$ the bulk thermal conductivity for the length of the borehole is $2.13 \mathrm{~W} \mathrm{~m}^{-1} \mathrm{~K}^{-1}$ for fracture saturation of $80 \%$ (in the $5 \mathrm{~m}$ unsaturated zone) and 
water level, the bulk thermal conductivities reduce to $2.03 \mathrm{~W} \mathrm{~m}^{-1} \mathrm{~K}^{-1}$ for fracture saturation of $80 \%$ (in the $40 \mathrm{~m}$ unsaturated zone) and $1.79 \mathrm{~W} \mathrm{~m}^{-1} \mathrm{~K}^{-1}$ for fracture saturation of $20 \%$.

234 The calculated thermal conductivities are apparent as they are dependent on the direction of heat flow, assumed to be vertical. In ground source heat applications that utilise a closed loop vertical borehole or thermal pile, the heat flow close to the borehole or pile will be horizontal. To examine this effect on the calculated thermal conductivity, the unfractured Chalk model of bedded chalk, marl seams and flint bands has been rerun using the arithmetic mean model since the heat flow is now parallel to the layering. The Middle and Lower Chalk are unchanged due to their lack of flint. The maximum change is an increase in thermal conductivity for the southern England/Thames and Chilterns Upper Chalk maximum model (15\% flint, 1.5\% marl) of $0.11 \mathrm{~W} \mathrm{~m}^{-1} \mathrm{~K}^{-1}$, a $5 \%$ increase. The increase is less for the mid-range models, e.g. for the southern England mid-range Upper Chalk model (3\% flint, 1.5\% marl) the thermal conductivity increases from 1.78 to $1.82 \mathrm{~W} \mathrm{~m}^{-1} \mathrm{~K}^{-1}$, a $2 \%$ increase. The fracture models have also been rerun with the arithmetic mean model for the bedding plane fractures (heat flow parallel to fracturing) and the harmonic mean model for the vertical fracturing (heat flow perpendicular to fracturing). Now, the maximum reduction in thermal conductivity for fractures in the saturated zone is $12 \%$. In the unsaturated zone, the reductions in thermal conductivity at a fracture volume of 0.03 , are $32 \%$ at $80 \%$ saturation and $63 \%$ at $20 \%$ saturation. These increases are a reflection of the greater fracture space in the vertical fracturing and the link to the heat flow direction in these models.

The modelled values in Table 5 can be compared to the measured thermal conductivities on core chippings listed in Table 1. For the southern province the measured values all agree with the modelled values to within the quoted accuracy of $10-15 \%$ and support the general conclusion of lower thermal conductivities for the Upper Chalk and lower thermal conductivities for the Middle and Lower Chalk of East Anglia compared to southern England. For northern England there is no agreement between Tables 1 and 5 and since the measured thermal conductivities are only possible if the chalk had no porosity, it is therefore concluded that the 
measured values are in error and should be discounted. Thermal conductivities are also available from thermal response tests (TRT) carried out in closed loop boreholes. These generate a bulk thermal conductivity which is an integrated value of thermal conductivity of the strata over the length of the borehole (Banks, 2008). The TRT measurements referenced here were all made in the saturated zone and hence the heat flow direction will only have a minor effect. Banks et al. (2013) reported the results of 61 UK TRTs and indicated that Chalk thermal conductivities of southern England fall within the range 1.7-2.0 W m $\mathrm{m}^{-1} \mathrm{~K}^{-1}$. Hemmingway and Long (2012) reported the results of a TRT in Norfolk from a $204 \mathrm{~m}$ deep borehole that penetrated $21 \mathrm{~m}$ of sand and gravel and $183 \mathrm{~m}$ of chalk with flint. The measured thermal conductivity was $1.9 \mathrm{~W} \mathrm{~m}^{-1} \mathrm{~K}^{-1}$, but if the ground is assumed to be horizontally layered then by applying the arithmetic mean model (heat flow assumed radial to the borehole) and assigning a thermal conductivity of $2.0 \mathrm{~W} \mathrm{~m}^{-1} \mathrm{~K}^{-1}$ to the sand and gravel (Clarke et al., 2008), then the chalk thermal conductivity calculates as $1.89 \mathrm{~W} \mathrm{~m}^{-1} \mathrm{~K}^{-1}$. From Table 5 the mid thermal conductivity value for East Anglian Upper Chalk is $1.87 \mathrm{~W} \mathrm{~m}^{-1} \mathrm{~K}^{-1}$, in close agreement with the TRT result. Loveridge et al. (2013) described the results of a TRT test from a borehole in east London that penetrated the Chalk between 56 and 150 m depth. Thermistors installed within the backfill of the borehole enabled an evaluation of thermal conductivity for specific borehole intervals rather than a single value for the entire borehole. A mean thermal conductivity for the Chalk derived from values in both the injection and recovery phases of the test was $2.03 \mathrm{~W}$ $\mathrm{m}^{-1} \mathrm{~K}^{-1}$. Chalk from this depth and location is White Chalk (Upper and Middle Chalk undivided) and the measured thermal conductivity is in accord with the southern England values in Table 5.

\section{Conclusions}

The thermal conductivity of the English Chalk has been estimated from multi-component mixture models. If the influence of fracturing is not taken into account, then the bulk thermal conductivity range of mid values is $1.78-2.57 \mathrm{~W} \mathrm{~m}^{-1} \mathrm{~K}^{-1}$ and the minimum to maximum range is $1.53-2.77 \mathrm{~W} \mathrm{~m}^{-1} \mathrm{~K}^{-1}$. Variations in porosity are the main factor for the variation in thermal 
conductivity. The effect of fracturing is to reduce the bulk thermal conductivity, but the reduction is small for fractures that are saturated. For an averagely fractured chalk with $60 \%$ fracture saturation, the reduction in thermal conductivity is around $22 \%$ for a thermal conductivity of $2.15 \mathrm{~W} \mathrm{~m}^{-1} \mathrm{~K}^{-1}$ (range; $18 \%$ reduction for $\lambda=1.65 \mathrm{~W} \mathrm{~m}^{-1} \mathrm{~K}^{-1}$ and $24 \%$ reduction for $\lambda=2.43 \mathrm{~W} \mathrm{~m}^{-1} \mathrm{~K}^{-1}$ ) and with $100 \%$ fracture saturation, the reduction is around $4 \%$ for a thermal conductivity of $2.15 \mathrm{~W} \mathrm{~m}^{-1} \mathrm{~K}^{-1}$ (range; $3 \%$ reduction for $\lambda=1.65 \mathrm{~W} \mathrm{~m}^{-1} \mathrm{~K}^{-1}$ and $4 \%$ reduction for $\left.\lambda=2.43 \mathrm{~W} \mathrm{~m}^{-1} \mathrm{~K}^{-1}\right)$. In the near surface zone, where fracture apertures will be at their greatest and unsaturated conditions may prevail for at least part of the year, the reduction will be most significant. As a first pass in selecting thermal conductivities for the Chalk, the mid layered values should be selected based on a classification of Upper, Middle or Lower Chalk in the southern or northern provinces. Where there is more detailed local knowledge on structure and the extent of the unsaturated zone the thermal conductivities can be reduced accordingly.

\section{Acknowledgements}

This paper is published by permission of the Executive Director of the British Geological Survey (NERC). Melinda Lewis and Andrew McKenzie of the BGS are thanked for review of the manuscript and for data on seasonal water level fluctuations in the Chalk.

\section{References}

Allen, D. J., Brewerton, L. J., Coleby, L. M., GibBs, B. R., LeWIS, M. A., MacDonald, A. M., WAGSTAFF, S. J., \& WILLIAMS, A. 1997. The physical properties of major aquifers in England and Wales. British Geological Survey Technical Report WD/97/34, 312pp.

BANKS, D. 2008. An Introduction to Thermogeology: Ground Source Heating and Cooling. Blackwell-Wiley, Oxford. 
Banks, D., Withers, J. G., CAShmore, G. \& Dimelow, C. 2013. An overview of the results of 61 in situ thermal response tests in the UK. Quarterly Journal of Engineering Geology, 46, 281-291.

BARKER, R. D. 1994. Some hydrogeological properties of the Chalk of Humberside and Lincolnshire. Quarterly Journal of Engineering Geology, 27, S5-S13.

Bevan, T. G. \& HancoCK, P. L. 1986. A late Cenozoic regional mesofracture system in southern England and northern France. Journal of the Geological Society London, 143, 355362.

BloOmer, J. R., KuCKes, A. F., OXBURGH, E. R. \& RichaRdSON, S. W. 1982. Heat flow studies in the Winterborne Kingston borehole, Dorset. In: RHYS, G. H., LOTT, G. K. \& CALVER, M. A. (Eds.) The Winterborne Kingston borehole, Dorset, England. Report of the Institute of Geological Sciences, No. 81/3, 176-183.

BLOOMFIELD, J. 1996. Characterisation of hydrogeologically significant fracture distributions in the Chalk: an example from the Upper Chalk of southern England. Journal of Hydrology, 184, 355-379.

Bloomfield, J. P., Brewerton, L. J., \& AlLen, D. J. 1995. Regional trends in matrix porosity and dry density of the Chalk of England. Quarterly Journal of Engineering Geology, 28, S131S142.

BRIGAUD, F. \& VASSEUR, G. 1989. Mineralogy, porosity and fluid control on thermal conductivity of sedimentary rocks. Geophysical Journal, 98, 525-542.

BROMLEY, R. G. 1967. Some observations on burrows of thalassinidean Crustacea in chalk hardgrounds. Quarterly Journal of the Geological Society London, 23, 157- 182.

Burgess, W. G., Burley, A. J., Downing, R. A., Edmunds, W. M. \& Price, M. 1981. The Marchwood geothermal borehole - a preliminary assessment of the resource. Investigation of the Geothermal Potential of the UK. British Geological Survey. 
ClaRke, B. G., AGAB, A. \& Nicholson, D. 2008. Model specification to determine thermal conductivity of soils. Proceedings of the Institution of Civil Engineers, Geotechnical Engineering, 161, 161-168.

ClAUSER, C., 2006. Geothermal Energy, In: K. HeINLOTH (Ed), Landolt-Börnstein, Group VIII: “Advanced Materials and Technologies", Vol. 3 "Energy Technologies”, Subvol. C “Renewable Energies”, 480 - 595, Springer Verlag, Heidelberg-Berlin.

Clauser, C. \& Huenges, E. 1995. Thermal conductivity of rocks and minerals. - In: AHRENS, T. J. (Ed.), Rock Physics \& Phase Relations: A Handbook of Physical Constants, American Geophysical Union, pp. 105-126. Destombes, J. P. \& ShePhARD-ThORN, E. R. 1971. Geological results of the Channel Tunnel site investigation 1964-65. Report. No. 71111. Institute of Geological Sciences, 12 pp.

DORNBUSCH, U. 2005. Contribution of flint shingle from cliff retreat and shore platform erosion. BAR Phase I, February 2003 - January 2005 Science Report. http://www.sussex.ac.uk/geography/researchprojects/BAR/publish/Phase-1-finalflint\%20contribution.pdf.

Dornbusch, U., Robinson, D. A., Moses, C. A. \& WiLliams, B. G. 2006. Chalk coast erosion and its contribution to the shingle budget in east Sussex. Zeitschrift fur Geomorphologie Supplementband, 144, 215-230.

Gale, I. N., \& RUtTER, H. K. 2006. The Chalk aquifer of Yorkshire. British Geological Survey Research Report, RR/06/04. 68pp.

GEBSKI, J. S., WheILDON, J. \& THOMAS-BeTtS, A. 1987. Investigations of the UK heat flow field (1984-1987). Investigation of the Geothermal Potential of the UK. British Geological Survey. HANCOCK, J. M. 1975. The petrology of the Chalk. Proceedings of the Geological Association, 86, 499-535. 
HemmingwAY, P. \& LONG, M. 2012. Design and development of a low-cost thermal response rig. Proceedings of the Institution of Civil Engineers, Energy, 165, 137-148.

HOPSON, P. M. 2005. A stratigraphical framework for the Upper Cretaceous Chalk of England and Scotland, with statements on the Chalk of Northern Ireland and the UK Offshore Sector. British Geological Survey Research Report RR/05/01, 102 pp.

HORAI, K. 1971. Thermal conductivity of rock forming minerals. Journal of Geophysical Research, 76, 1278-1308.

JONES, H. K., \& ROBINS, N. S. (editors). 1999. The Chalk aquifer of the South Downs. Hydrogeological Report Series of the British Geological Survey.

KNUTSSON, S. 1983. On the thermal conductivity and thermal diffusivity of highly compacted bentonite. SKBF/KBS Report TR 83-72, University of Lulea, Sweden.

Loveridge, F., Holmes, G., PoWrie, W. \& Roberts, T. 2013. Thermal response testing through the Chalk aquifer in London, UK. Proceedings of the Institution of Civil Engineers, Geotechnical Engineering, 166, 197-210.

MORGAN-JONES, M. 1977. Mineralogy of the non-carbonate material from the Chalk of Berkshire and Oxfordshire, England. Clay Minerals, 12, 331-344.

MORTIMORE, R. N. 1986. Stratigraphy of the Upper Cretaceous White Chalk of Sussex.

Proceedings of the Geologists' Association, Vol. 97, No. 2, 97-139.

MORTIMORE, R. N. 2001. Chalk: a stratigraphy for all reasons. Geoscience in south-west England, 10, 105-122.

MORTIMORE, R. 2011. A chalk revolution: what have we done to the Chalk of England?

379 Proceedings of the Geologists' Association, 122, 232-297.

MORTIMORE, R. N. 2012. Making sense of Chalk: a total-rock approach to its Engineering 381 Geology. Quarterly Journal of Engineering Geology, 45, 252-334. 
Mortimore, R., Newman, T. G., Royse, K., Scholes, H. \& LaWrence, U. 2001. Chalk: its stratigraphy, structure and engineering geology in east London and the Thames Gateway. Quarterly Journal of Engineering Geology, 44, 419-444.

MORTIMORE, R.N. \& WOOD, C.J. 1986. The distribution of flint in the English Chalk, with particular reference to the 'Brandon Flint Series' and the high Turonian flint maximum. In: SieVeking, G., DE, G. \& Hart, M.B. (eds) The Scientific Study of Flint and Chert. Cambridge University Press, Cambridge, 7-20.

OzBeK, H. \& PhILLIPS, S. 1979 . Thermal conductivity of aqueous $\mathrm{NaCl}$ solutions from $20{ }^{\circ} \mathrm{C}$ to $330{ }^{\circ} \mathrm{C}$. University of California, LBL Report No. 9086, Berkeley, USA, pp 22.

PATSOULES, M. G. \& CRIPPS, J. C. 1990. Survey of macro and micro faulting in Yorkshire chalk. In: Proc. Int. Chalk Symposium, Brighton, 1989, Thomas Telford, London, 87-93.

SOMERTON, W. H. 1992. Thermal properties and temperature-related behaviour of rock/fluid systems. Elsevier.

WheILdON, J., GeBsKI, J. S. \& ThOMAS-BetTS, A. 1985. Further Investigations of the UK heat 396 flow field (1981-1984). Investigation of the Geothermal Potential of the UK. British Geological 397 Survey.

WRAY, D. S. \& JEANS, C. V. 2014. Chemostratigraphy and provenance of clays and other non-carbonate minerals in chalks of Campanian age (Upper Cretaceous) from Sussex, southern England. Clay Minerals, 49, 327-340.

401 YOUNGER, P. L. \& ELLIOT, T. 1995. Chalk fracture system characteristics: implications for flow and solute transport. Quarterly Journal of Engineering Geology, 28, S39-S50. 


\section{$1 \quad$ Figure and Table captions}

2 Figure 1. Geographical areas of the English Chalk superimposed on the Chalk outcrop 3 (shaded grey), after Bloomfield et al. (1995).

4 Figure 2. Schematic diagram of chalk used for the modelling comprising chalk matrix, flint

5 layers, marl seams and fractures. The thermal conductivity of the chalk matrix was calculated 6 with the geometric mean. With an assumed vertical heat flow, the thermal conductivity of the 7 horizontal model components was calculated with the harmonic mean and the vertical components with the arithmetic mean. Note: $\lambda$ is the combined thermal conductivity, $\lambda_{i}$ is the thermal conductivity and $\phi_{i}$ is the volume fraction of the ith phase respectively.

Figure 3. Plot of thermal conductivity against fracture space by proportional volume for a model with a layered thermal conductivity of $2.15 \mathrm{~W} \mathrm{~m}^{-1} \mathrm{~K}^{-1}$ with a bedding plane fracture volume of $0.0001-0.014$ and a vertical fracture volume of $0.0005-0.05$. Fracture saturations from $0-100 \%$ are shown where the saturated volume is water and the unsaturated volume is air.

Table 1. Laboratory measured mean thermal conductivities of the English Chalk as reported in the literature. The porosity and state of saturation of the samples was not recorded at the time of measurement. Note; the method of measurement is indicated in brackets against the number of samples, where NP is the needle probe and PDB is the divided bar apparatus used on drill chippings placed in a pill box.

Table 2. The old (Traditional) and new Chalk lithostratigraphy after Mortimore et al. (2001) and Hopson (2005).

Table 3. Input data for the multi-component mixture models. Three porosities are shown for each Chalk unit corresponding to the $10^{\text {th }}, 50^{\text {th }}$ and $90^{\text {th }}$ percentiles of measured porosities from Bloomfield et al. (1995) except for the northern England Lower Chalk which is from Barker (1994) and comprises the mean with minimum and maximum porosities estimated as two standard deviations from the mean. Where flint is included in the model it ranges from 1.5-3$15 \%$ by volume. Abbreviations used for the mineral descriptions are explained in Table 4. 
27 Table 4. Thermal conductivities assigned to the model components.

28 Table 5. Results from the multi-component mixture models for the English Chalk comprising

29 the layered thermal conductivities, i.e. bulk thermal conductivities if the influence of fracturing

30 is not taken into account. The results are tabulated as minimum, mid and maximum for each

31 Chalk unit. 


\begin{tabular}{|c|c|c|c|c|c|}
\hline & \multicolumn{2}{|c|}{ 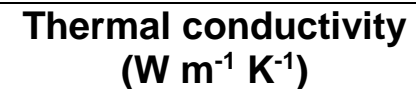 } & \multirow[t]{2}{*}{$\begin{array}{c}\text { No. of } \\
\text { samples }\end{array}$} & \multirow[t]{2}{*}{ Borehole } & \multirow[t]{2}{*}{ Reference } \\
\hline & $\begin{array}{l}\text { Southern } \\
\text { Province }\end{array}$ & $\begin{array}{l}\text { Northern } \\
\text { Province }\end{array}$ & & & \\
\hline \multirow[t]{3}{*}{ Upper Chalk } & $1.71 \pm 0.05$ & & $14(\mathrm{NP})$ & Southampton & Wheildon et al. (1985) \\
\hline & $1.56 \pm 0.02$ & & $24(N P)$ & Stowlangtoft & Wheildon et al. (1985) \\
\hline & & $3.27 \pm 0.1$ & 6 (PDB) & Cleethorpes & Gebski et al. (1987) \\
\hline \multirow[t]{3}{*}{ Middle Chalk } & $2.44 \pm 0.18$ & & $3(\mathrm{NP})$ & Southampton & Wheildon et al. (1985) \\
\hline & $1.58 \pm 0.02$ & & $20(N P)$ & Stowlangtoft & Wheildon et al. (1985) \\
\hline & & $3.42 \pm 0.18$ & 3 (PDB) & Cleethorpes & Gebski et al. (1987) \\
\hline \multirow[t]{5}{*}{ Lower Chalk } & $1.71 \pm 0.04$ & & $2(\mathrm{NP})$ & Harwell No. 3 & Wheildon et al. (1985) \\
\hline & $2.36 \pm 0.27$ & & 4 (NP) & Southampton & Wheildon et al. (1985) \\
\hline & $2.37 \pm 0.21$ & & $8(\mathrm{NP})$ & $\begin{array}{l}\text { Winterborne } \\
\text { Kingston }\end{array}$ & Bloomer et al. (1982) \\
\hline & $1.67 \pm 0.02$ & & $15(\mathrm{NP})$ & Stowlangtoft & Wheildon et al. (1985) \\
\hline & & 3.83 & 1 (PDB) & Cleethorpes & Gebski et al. (1987) \\
\hline $\begin{array}{l}\text { Chalk } \\
\text { (undifferentiated) }\end{array}$ & $1.79 \pm 0.54$ & & 41 (PDB) & Marchwood & Burgess et al. (1981) \\
\hline
\end{tabular}




\begin{tabular}{|c|c|c|c|c|}
\hline \multirow{2}{*}{ Stage } & \multirow{2}{*}{$\begin{array}{l}\text { Old Chalk } \\
\text { Stratigraphy }\end{array}$} & \multicolumn{3}{|c|}{ New Chalk Stratigraphy } \\
\hline & & Subgroup & $\begin{array}{c}\text { Southern Province } \\
\text { Formations }\end{array}$ & $\begin{array}{c}\text { Northern Province } \\
\text { Formations }\end{array}$ \\
\hline \multirow{2}{*}{ Campanian } & \multirow{6}{*}{ Upper Chalk } & \multirow{9}{*}{ White Chalk } & Portsdown Chalk & Rowe Chalk \\
\hline & & & Culver Chalk & \multirow[t]{3}{*}{$\begin{array}{l}\text { Flamborough } \\
\text { Chalk }\end{array}$} \\
\hline \multirow{2}{*}{ Santonian } & & & Newhaven Chalk & \\
\hline & & & Seaford Chalk & \\
\hline Coniacian & & & Lewes Nodular & \multirow[t]{2}{*}{ Burnham Chalk } \\
\hline \multirow{3}{*}{ Turonian } & & & & \\
\hline & \multirow{2}{*}{ Middle Chalk } & & & \multirow{3}{*}{ Welton Chalk } \\
\hline & & & & \\
\hline \multirow{3}{*}{ Cenomanian } & \multirow{3}{*}{ Lower Chalk } & & Chalk & \\
\hline & & \multirow{2}{*}{ Grey Chalk } & Zig Zag Chalk & \multirow{2}{*}{ Ferriby Chalk } \\
\hline & & & $\begin{array}{l}\text { West Melbury } \\
\text { Marly Chalk }\end{array}$ & \\
\hline
\end{tabular}




\begin{tabular}{|c|c|c|c|c|c|c|c|}
\hline \multirow{2}{*}{ Southern Province } & \multirow{2}{*}{$\begin{array}{c}\text { Matrix } \\
\text { mineralogy }\end{array}$} & \multicolumn{4}{|c|}{ Porosity (\%) } & \multirow{2}{*}{\begin{tabular}{|l|} 
Marl seams \\
$53.9 \% \mathrm{CaCO}_{3}$, \\
$23.1 \% \mathrm{Sme}$, \\
$23 \% \mathrm{H}_{2} \mathrm{O}$
\end{tabular}} & \multirow{2}{*}{$\begin{array}{c}\text { Flint } \\
\text { bands }\end{array}$} \\
\hline & & $\begin{array}{l}\text { Southern } \\
\text { England }\end{array}$ & $\begin{array}{l}\text { Thames \& } \\
\text { Chilterns }\end{array}$ & $\begin{array}{l}\text { East } \\
\text { Anglia }\end{array}$ & \begin{tabular}{|l} 
Northern \\
England
\end{tabular} & & \\
\hline Upper Chalk & $\begin{array}{l}97 \% \mathrm{CaCO}_{3}, 1 \% \mathrm{Qtz}, \\
1 \% \mathrm{Mnt}, 0.33 \% \mathrm{ll}, \\
0.33 \% \mathrm{Glt} .033 \% \mathrm{Ms}\end{array}$ & $\begin{array}{l}31.7 \\
39.8 \\
44.7\end{array}$ & $\begin{array}{l}31.7 \\
39.8 \\
44.7\end{array}$ & $\begin{array}{l}29.4 \\
37.1 \\
48.1\end{array}$ & & $1.5 \%$ & $\begin{array}{l}1.5 \% \\
3.0 \% \\
15.0 \%\end{array}$ \\
\hline Middle Chalk & $\begin{array}{l}97 \% \mathrm{CaCO}_{3}, 1 \% \mathrm{Qtz}, \\
1 \% \text { Mnt, } 0.33 \% \mathrm{ll}, \\
0.33 \% \mathrm{Glt} \text {, } 0.33 \% \mathrm{Ms}\end{array}$ & $\begin{array}{l}22.3 \\
28.3 \\
350\end{array}$ & $\begin{array}{l}24.0 \\
31.8 \\
39.5\end{array}$ & $\begin{array}{l}27.4 \\
33.6 \\
42.4\end{array}$ & & $1.5 \%$ & no flint \\
\hline Lower Chalk & $\begin{array}{l}70 \% \mathrm{CaCO}_{3}, 15 \% \mathrm{KLn} \text {, } \\
4 \% \mathrm{Sme}, 4 \% \mathrm{lll}, \\
4 \% \mathrm{Mnt}, 1.5 \% \mathrm{Qtz}, \\
1.5 \% \mathrm{Fsp}\end{array}$ & $\begin{array}{l}13.3 \\
22.9 \\
34.2\end{array}$ & $\begin{array}{l}16.3 \\
27.0 \\
35.5\end{array}$ & $\begin{array}{l}27.4 \\
33.6 \\
42.4\end{array}$ & & $\begin{array}{l}\text { Incorporated in } \\
\text { matrix }\end{array}$ & no flint \\
\hline \multicolumn{8}{|l|}{ Northern Province } \\
\hline Upper Chalk & $\begin{array}{l}98 \% \mathrm{CaCO}_{3}, \\
0.25 \% \mathrm{Qtz}, 0.875 \% \mathrm{III} \\
0.875 \% \mathrm{Mnt}\end{array}$ & & & & \begin{tabular}{|l|}
23.8 \\
38.0 \\
41.2
\end{tabular} & $3 \%$ & $\begin{array}{l}1.5 \% \\
3.0 \% \\
15.0 \%\end{array}$ \\
\hline Middle Chalk & $\begin{array}{l}98 \% \mathrm{CaCO}_{3} \\
0.25 \% \mathrm{Qtz}, 0.875 \% \mathrm{lll}, \\
0.875 \% \mathrm{Mnt}\end{array}$ & & & & \begin{tabular}{|l|}
13.7 \\
18.0 \\
24.7 \\
\end{tabular} & $1 \%$ & no flint \\
\hline Lower Chalk & $\begin{array}{l}70 \% \mathrm{CaCO}_{3}, 14 \% \mathrm{lll}, \\
14 \% \mathrm{Mnt}, 1 \% \mathrm{Qtz} \\
1 \% \mathrm{Fsp}\end{array}$ & & & & \begin{tabular}{|l|}
17.6 \\
20.6 \\
23.6
\end{tabular} & $\begin{array}{l}\text { Incorporated in } \\
\text { matrix }\end{array}$ & no flint \\
\hline
\end{tabular}




\begin{tabular}{|l|l|l|l|}
\hline Model component & Abbreviation & $\begin{array}{c}\text { Thermal } \\
\text { conductivity } \\
\left(\mathbf{W} \mathbf{~ m}^{-1} \mathbf{K}^{-1} \mathbf{)}\right.\end{array}$ & \multicolumn{1}{|c|}{ Reference } \\
\hline Air & & 0.024 & Banks (2008) \\
\hline Calcium Carbonate & $\mathrm{CaCO}_{3}$ & 3.59 & Clauser and Huenges (1995) \\
\hline Feldspar & $\mathrm{Fsp}$ & 2.12 & Clauser and Huenges (1995) \\
\hline Flint & & 3.7 & Horai (1971) \\
\hline Glauconite & Glt & 1.63 & Horai (1971) \\
\hline Illite & $\mathrm{II}$ & 1.85 & Brigaud and Vasseur (1989) \\
\hline Kaolinite & $\mathrm{Kln}$ & 2.64 & Brigaud and Vasseur (1989) \\
\hline Montmorillonite & $\mathrm{Mnt}$ & 1.4 & Knutsson (1983) \\
\hline Muscovite & $\mathrm{Ms}$ & 2.32 & Horai (1971) \\
\hline Quartz & $\mathrm{Qtz}$ & 7.69 & Clauser and Huenges (1995) \\
\hline Smectite & $\mathrm{Sme}$ & 1.88 & Brigaud and Vasseur (1989) \\
\hline Water & $\mathrm{H}_{2} \mathrm{O}$ & 0.6 & Ozbek and Phillips (1979) \\
\hline
\end{tabular}




\begin{tabular}{|c|c|c|c|c|c|c|r|r|r|r|r|r|}
\hline & \multicolumn{10}{|c|}{ Thermal conductivity $\left(\mathbf{W} \mathbf{~ m}^{-1} \mathbf{K}^{-1}\right)$} \\
\cline { 2 - 13 } & \multicolumn{3}{|c|}{ Southern England } & \multicolumn{3}{|c|}{$\begin{array}{c}\text { Thames \& } \\
\text { Chilterns }\end{array}$} & \multicolumn{3}{c|}{ East Anglia } & \multicolumn{3}{c|}{ Northern England } \\
\hline & min & mid & max & min & mid & max & min & mid & max & min & mid & max \\
\hline Upper Chalk & 1.63 & 1.78 & 2.17 & 1.63 & 1.78 & 2.17 & 1.53 & 1.87 & 2.25 & 1.73 & 1.84 & 2.45 \\
\hline Middle Chalk & 1.91 & 2.15 & 2.39 & 1.77 & 2.02 & 2.32 & 1.68 & 1.96 & 2.18 & 2.28 & 2.57 & 2.77 \\
\hline Lower Chalk & 1.78 & 2.15 & 2.52 & 1.75 & 2.01 & 2.40 & 1.56 & 1.80 & 2.00 & 1.99 & 2.08 & 2.18 \\
\hline
\end{tabular}




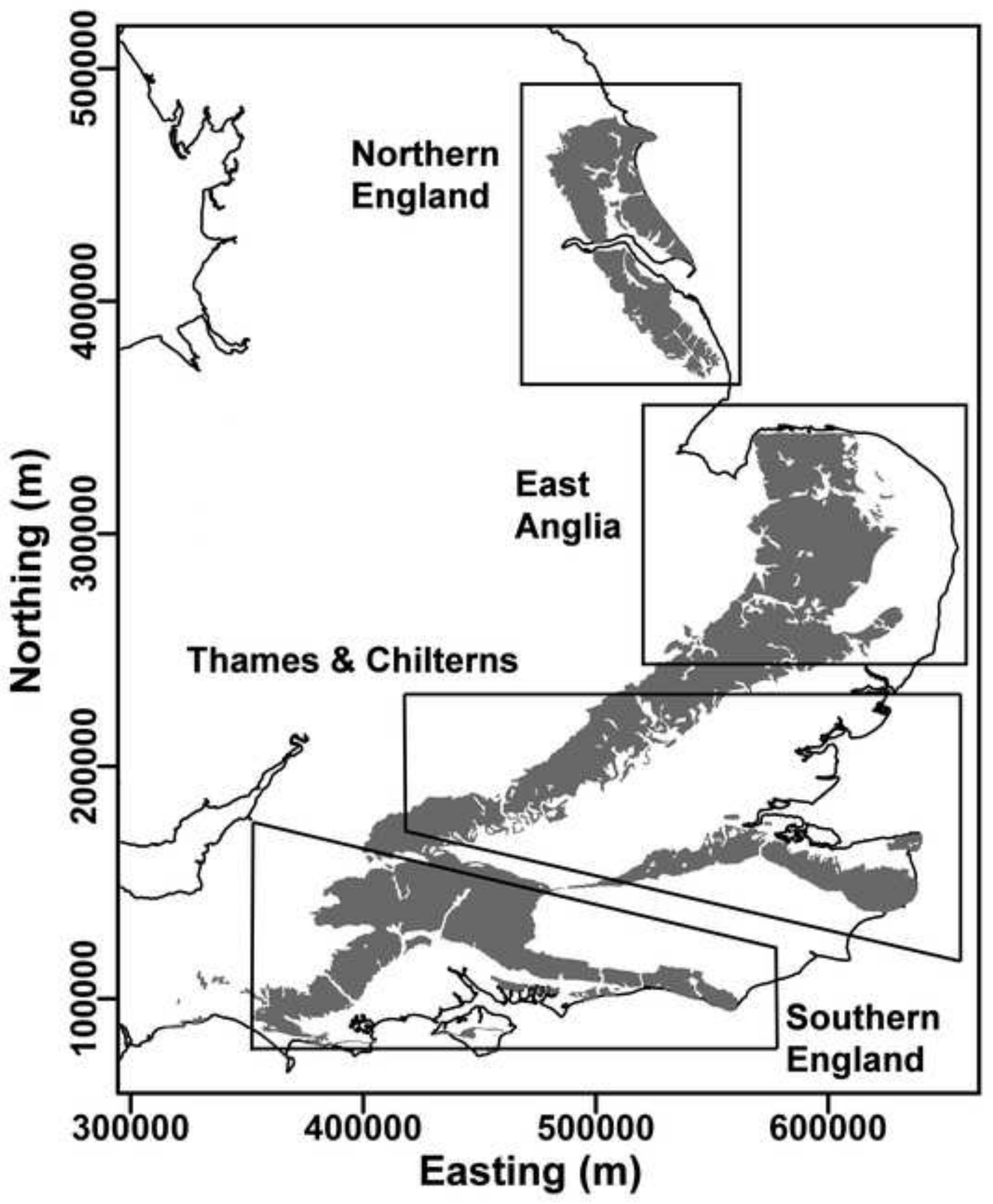


Harmonic mean for layering perpendicular to heat flow, i.e., flint

layers, marl seams

Geometric mean for chalk matrix

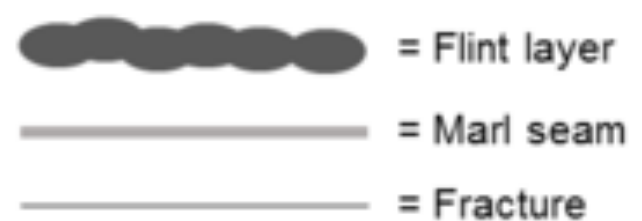

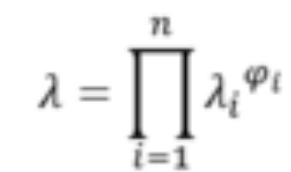

Arithmetic mean for layering parallel to heat flow, i.e., vertical fractures $\lambda=\sum_{i=1}^{n} \varphi_{i} \lambda_{i}$

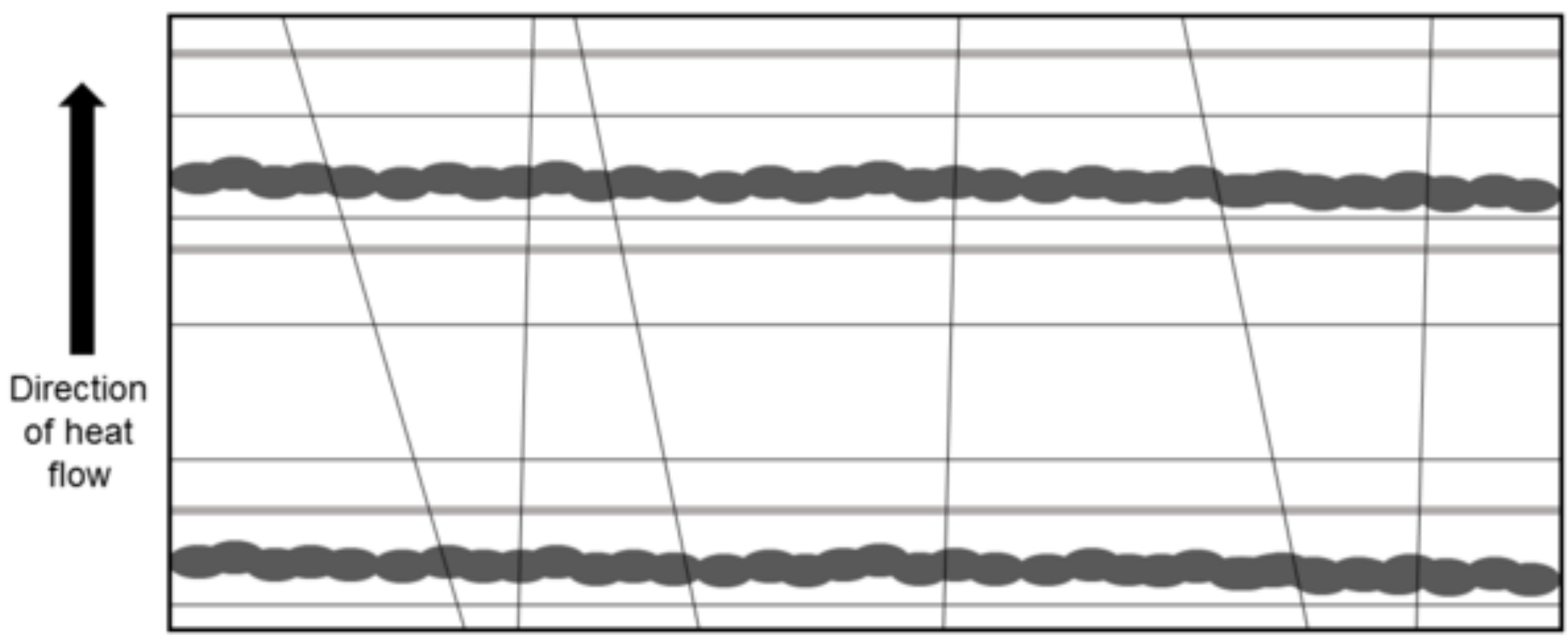




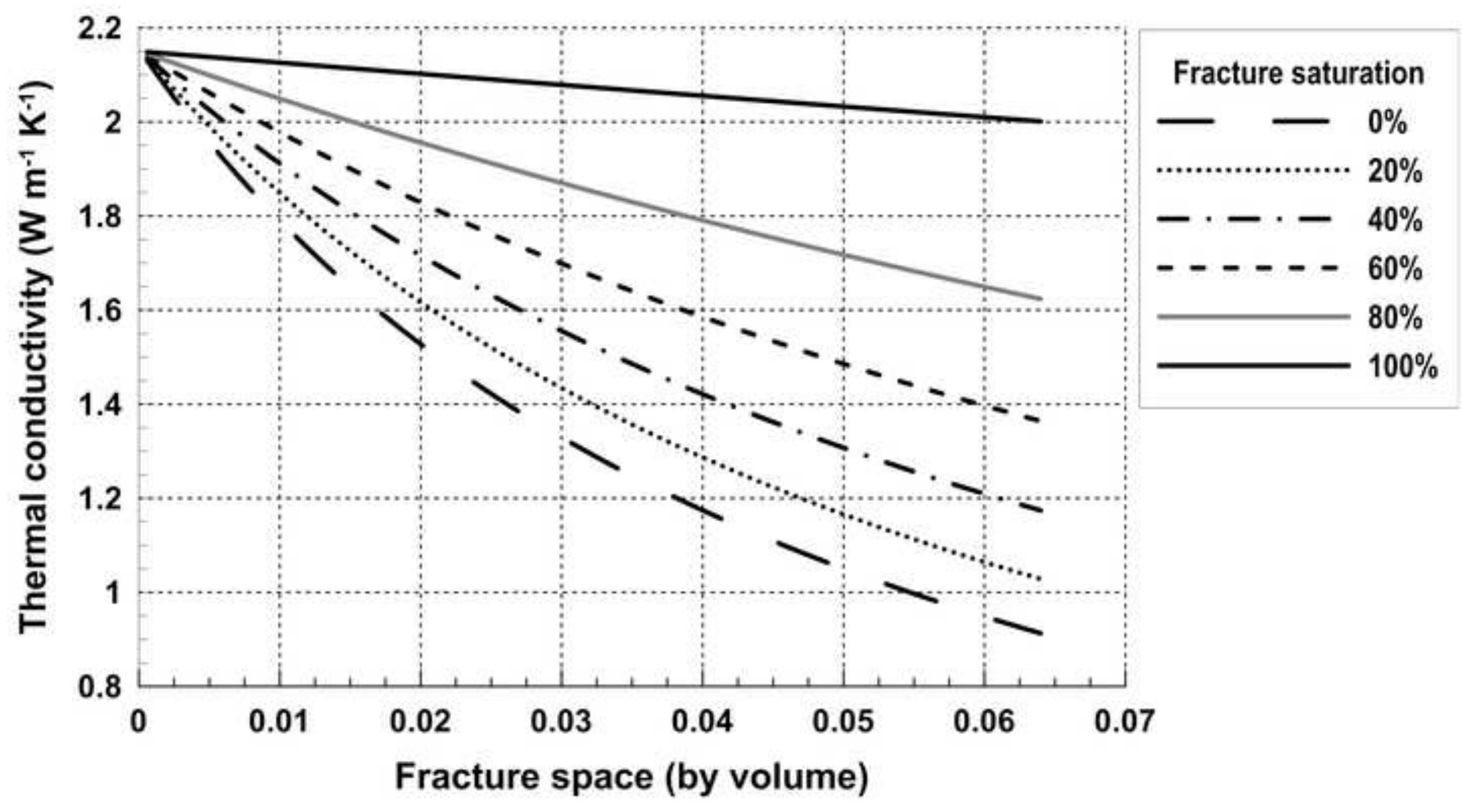

